\title{
Arabic in the context of comparative studies*
}

\begin{abstract}
The paper discusses certain characteristics of Arabic that define its position in Semitic comparative studies and are determined not only by Arabic language structures at different levels, but also by extra-linguistic factors, viz. socio-cultural and psychological. This combination of both linguistic and extra-linguistic factors makes Arabic a special phenomenon among languages of the world. Before discussing the place of Arabic in Semitic studies, I present a brief overview of the history of intra-Semitic comparisons prior to the emergence of contemporary comparative linguistics and to the role of Arabic medieval grammar tradition in this respect. The next section focuses on the role of Arabic as a model for proto-Semitic reconstructions and on the drastic changes that it underwent over the history of comparative Semitic studies. The last section discusses certain specific features of Arabic and Semitic phonetics and lexicon and their correlation with the standard Neogrammarian paradigm of comparative linguistics. These issues deserve special attention, since theories based on these phenomena contradict the standard paradigm of comparative linguistics, and the Arabic language may be regarded as an archetypal case of these phenomena.
\end{abstract}

Keywords: comparative linguistics, Semitic languages, Arabic, Neogrammarian paradigm, regular correspondences, reconstruction, binary opposition, perfective aspect, imperfective aspect, historical typology.

In this paper, I would like to discuss the place and role of Arabic in Semitic comparative studies and historical reconstructions. In the beginning we shall focus on the history of intraSemitic comparisons and the role that Hebrew-Aramaic biblical studies and medieval Arabic grammar traditions play within this framework. Following that, we shall discuss the status of Arabic as a model in Semitic reconstructions at different stages of development of Semitic comparative historical linguistics. In the early period of modern Semitic studies standard Arabic was duly considered the most archaic of the living Semitic languages. Although the task of establishing regular sound correspondences between classical Semitic languages was accomplished, these correspondences were, in fact, graphic and not phonetic in the proper sense of the word; their phonetic value was established mostly on the basis of classical Arabic pronunciation. Only at the later stages were the data from Modern South Arabian and Ethiopian Semitic included into comparative Semitic studies on par with classical languages, and this brought serious changes to the comparative panorama of Semitic. Special attention will be paid to the reconstruction of the Semitic verbal system according to the model worked out by the present author, as well as the place of Arabic in this model. Finally, particular attention will be devoted to the evolution of the status of Arabic as a model for proto-Semitic reconstructions. The last part of the paper is dedicated to different attempts to consider certain features of Arabic and Semitic phonetics and lexicon as a source for inferring glottogonic processes. These trends contradict standard Neogrammarian paradigms and deserve special discussion.

* Work on the present paper was supported by grant №14-04-00488 (2014-2016) of the Russian Scientific Fund for the Humanities.

Journal of Language Relationship • Вопросы языкового родства • 14/2 (2016) • Pp. 107-117• () The author, 2016 
1. It is a matter of general knowledge that comparative studies and linguistic reconstructions emerged at the beginning of the $19^{\text {th }}$ century on the basis of Indo-European languages. This was quite logical, since the new scientific theory was essentially based on data from European languages, well known to European scholars. Moreover, the notions of basic European ethno-linguistic units (such as Celtic, Germanic, Slavonic, etc.) had also been formed by that time. These notions were mostly based on general impressionistic criteria that included language, culture, oral traditions etc. (cf. the classification of languages by J. Scaliger and the development of this approach by G. W. Leibniz). A major breakthrough, i. e. the formation of a new linguistic discipline - comparative historical linguistics - was triggered by the inclusion of Sanskrit into European philological discourse.

As to Semitic languages, we already attest them in the earliest attempts at language comparison; suffice it to mention Targumim (Aramaic translations of Biblia Hebraica). Édouard Dhorme, one of the eminent scholars in the field of Semitic and Biblical studies, had noted in his introduction to the Pléiade French version of the Old Testament that these Aramaic versions were rather interpretations than mere translations of the Hebrew Holy Script [Dhorme 1956: XXV]. The text of the Biblia Hebraica abounds in 'dark passages', hapax legomena etc. It means that generations of highly trained scholars minutely and thoroughly studied and compared every word and every sentence in these two closely related languages in order to understand and comment on every letter of the Biblia Hebraica. We should emphasize here that Biblia Hebraica includes a rich collection of different texts (prosaic and poetic, philosophical and historical), created over the span of many centuries; there is arguably no other example of such a deep, intensive and protracted tradition of text collation. As a sidenote, it may be added that the famous Biblical episode of "shibboleth sibboleth" (Judges 12,6), which in all probability is the earliest attested case of the use of phonetic isoglosses for ethnic differentiation, is due to this tradition of text collation. In this case, it is not an instance of an Aramaic vs. Hebrew opposition, cf. the comment to this passage by Édouard Dhorme: "La population d'Éphraïm se distinguait des autres tribus par une prononciation défectueuse de la chuintante shin qui devenait sin dans leur bouche [Dhorme 1956: 770, footnote 6].

Traditions of Aramaic-Hebrew comparisons developed in the epoch of medieval Arabic and Hebrew grammatical schools. Medieval Semitic grammatical traditions first emerged within the framework of Arabic studies, but very quickly began to include Hebrew as well. The main principles, notions and paradigms of medieval Arabic grammars were successfully applied to Hebrew data. This symbiosis was so deep that there were instances of writing in Arabic using Hebrew letters and the other way round; consequently, Arabic also began to be included into Hebrew-Aramaic comparisons. Thus, "Risāla", the major work by Yehuda ibn Quraish (10 th century AD), is divided into three parts:

- comparison of Hebrew and Aramaic;

- explication of 17 hapaxes;

- comparison of Hebrew and Arabic (Cassuto 2007: 17).

I think there is every reason to consider Arabic-Hebrew medieval grammar traditions as the Golden Age of comparative Semitic studies, although this by no means signifies that these medieval grammar traditions should be considered a part of contemporary comparative linguistics. The point is that they are more extensive and better developed than those that existed in the European philology of the same period. It may be added that many of the principles and ideas of medieval Arab grammarians are still present in modern linguistic discourse.

Nevertheless, the theory and methodology of modern comparative historical linguistics was eventually worked out by specialists in Indo-European languages, based on European 
philological traditions. By the end of the $19^{\text {th }}$ century, a new theoretical approach to comparative analysis was codified by a group of specialists in Indo-European linguistics known as Neogrammarians (Young Grammarians, Junggrammatiker); the key point of their theory was identified as the principle of regular sound correspondences, metaphorically labeled 'sound laws'. From that time on, Neogrammarian principles have functioned as the base paradigm of comparative linguistics (on paradigms in the sense of [Kuhn 1962], see additional notes below).

2. The task of establishing regular sound correspondences between classical Semitic languages was accomplished without major problems. Incidentally, regular sound correspondences served as a solid base for deciphering and reading of the ancient written monuments in different extinct Semitic languages, which in its turn supplied new data for comparative studies. However, as a matter of fact, these correspondences were graphic, rather than phonetic in the proper sense of the word. The phonetic value of the graphemes used in ancient Semitic writing systems and incorporated into the system of regular sound correspondences was established mostly on the basis of traditional Arabic pronunciation, which served as a model for the common Semitic phonetic system. This was one of the reasons why in the early period of Semitic studies classical Arabic was considered the most archaic among the living Semitic languages. Moreover, medieval Arab grammarians had left very good descriptions of classical Arabic pronunciation. All of this made the Arabic language extremely important for comparative Semitic linguistics.

Another characteristic also contributed a lot to the status of Arabic as a model for protoSemitic reconstructions - namely, the remarkable stability of its consonantal root structures, which are practically not liable to conditioned phonetic changes (assimilations, dissimilations etc.). Even more striking is the presence of complex, but perfectly transparent and consistent Arabic morphological structures with minimal exceptions. During the earlier stages of historical studies language structures of this type were considered as the most archaic, even prototypical, not "spoiled" by later development (cf. the status of Sanskrit in early Indo-European studies). However, gradually it became evident that such morphological structures may rather result from intensive processes of analogical leveling, with an additional role played by the efforts of medieval philologists in the codification of classical Arabic (and similar reasoning may be applicable to classical Sanskrit).

Only at the later stages of the development of Semitic linguistics were the data from Modern South Arabian and Ethiopian Semitic included into comparative Semitic studies on par with classical languages, and this brought serious changes to the Semitic comparative perspective. Arabic could no longer be considered as the privileged model for phonetic reconstructions, even though generations of Semitologists continued to reject the idea to consider nonwritten languages of Southern Arabia, Soqotra, and Ethiopia of equal importance for protolanguage reconstructions with the classical extinct languages of some of the greatest world civilizations and religions. This drastic change of approach to Semitic reconstruction led to two most important reconsiderations:

- reconstruction of glottalized emphatic consonants instead of pharyngealized ones (the latter reconstruction was based on traditional Arabic pronunciation);

- reconstruction of lateral sibilants on the basis of Modern South Arabian pronunciation. Incidentally, this reconstruction allowed to explain the historical phonetic value of Hebrew sin and Arabic $¥ a d$.

The historical shift from glottalization to pharyngealization in Arabic can be accounted for by the affricate theory worked out by Igor Diakonoff (1988: 36-39). According to Diakonoff's 
reconstruction, phonemes that were traditionally interpreted as sibilant fricatives actually reflect of Proto-Semitic affricates. Phonetically, glottalized consonants are double-peak (or bifocal), the second occlusion being the glottal stop; turning into fricatives, affricates lost the main occlusion. It is true that glottalized sibilants are attested in certain languages (cf. glottalized s' in some Hausa dialects); however, they still cannot be considered as "proper" fricatives, since they preserve the glottal stop. This phonetically awkward situation could quite naturally lead to the shift from glottalization to pharyngealization in emphatic sibilant fricatives, whereas occlusive emphatics remained glottalized. Such a situation is attested in Modern South Arabian (Naumkin, Porkhomovsky 1988: 12-13). In Arabic, emphatic plosives also lost glottalization due to analogical change.

Turning to morphology, I shall focus on the verbal system as the key aspect for comparative studies and historical reconstructions. Together with North-Central Semitic (Hebrew, Aramaic, Phoenician etc.), Arabic was considered as a prototypical morphological model during the first decades of comparative Semitic. Later, with the progress of Assyriology, data from Akkadian language stock were included into comparative Semitic studies. Despite some obvious parallels, Akkadian verbal morphology on the whole is not historically compatible with Central Semitic, yet it also could not easily be explained away as a secondary development because of its obvious antiquity. Thus, for a certain time two incompatible morphological models co-existed in Semitic comparative linguistics.

This problem was the main reason for a paradoxical statement by A. Meillet:

... toutes les langues indo-européennes sont des formes différenciées d'une seule et même langue... Les langues sémitiques sont plus semblables entre elles que ne le sont les langues indo-européennes; à les observer, on a souvent l'impression de formes diverses d'une même langue plutôt que de langues vraiment différenciées, comme le sont les langues indo-européennes; et malgré cela, on n’arrive pas à poser un "sémitique commun", un Ursemitisch, comme on pose un "indo-européen commun", un Urindogermanisch. En particulier, l'akkadien (babylonien) offre des traits qui diffèrent tout à fait de ceux qu'on observe dans le groupe de l'hébréo-phénicien, de l'araméen, de l'arabe. (...) Néanmoins, la famille sémitique - y compris l'akkadien - est nettement définie, et l'on a ici un ensemble qui est aisément reconnaissable, plus même que ne l'est celui des langues indo-européennes. (Meillet 1927: 445)

Still later, the data from Modern South Arabian and Ethiopian Semitic formed a third nucleus in the common Semitic verbal panorama, making the whole situation even more paradoxical. There were numerous attempts to preserve the traditional approach by interpreting fully vocalized prefix-conjugated Imperfective ${ }^{1}$ forms in Modern South Arabian and Ethiopian Semitic as a later secondary development and not as genetic isoglosses with similar Akkadian forms; were these isoglosses accepted, Arabic, Hebrew, and other Central Semitic languages would lose their status of archaic, even prototypical Semitic languages - instead, it would be necessary to consider them as the most innovative languages in the field of verbal morphology, even more innovative than unwritten Modern South Arabian or Ethiopian Semitic languages. Earlier, I have proposed (see Porkhomovsky 1997, 2001/2, 2008) a new model of reconstruction for the Proto-Semitic verbal system which was based not on the traditional approach, viz. comparative analysis of forms according to Neogrammarian standards, but rather on diachronic typology. Reconstruction based on diachronic typological analysis of the respective morphological paradigms rather than individual forms was suggested as the first diachronic

${ }^{1}$ It should be noted that in the discussion below the terms "Perfective" and "Imperfective" are used as conventional labels for members of the basic binary aspect opposition. In specific languages they are often assigned temporal semantic values, i.e. "Past" and "Present" respectively. 
step, after which it was possible to explain the changes in verbal systems as a development of particular Semitic language groups or individual languages.

This diachronic typological model may be summarized as follows. Within the framework of the postulated common Semitic binary opposition "Perfective vs. Imperfective", both members were prefix-conjugated with full vocalism in Imperfective (formed by - $a$-Ablaut in the first syllable and gemination of the second root consonant in certain languages) and reduced vocalism in Perfective. In derived verbal stems (stirps) the situation may be more complex. The form of Perfective was weak (unmarked); it was also used in special syntactic constructions, in negative constructions, and as Jussive/Subjunctive, at the same time preserving its semantic value of Perfective. This situation demanded the formation of a new strong Perfective. Such an archaic situation is attested in Akkadian where the new Perfective is based on the derived verbal form with the infix -t-. In all other Semitic languages the new Perfective is a suffix-conjugated form, parallel to Akkadian Stative or Permansive (which is not a finite verbal form in Akkadian). In Modern South Arabian and Ethiopian Semitic the old prefixconjugated Perfective with reduced vocalism is used only as Jussive/Subjunctive. The fully vocalized prefix-conjugated Imperfective is preserved.

Arabic and other Central Semitic languages represent a new step in the development of the verbal system. Since the opposition between Perfective and Imperfective has come to be expressed by the opposition of suffix- versus prefix-conjugated forms respectively, the existence of two prefix-conjugated forms became redundant. The fully vocalized form was lost and the form with reduced vocalism preserved its functions as Jussive/Subjunctive, but also acquired functions of Imperfective. However, in certain cases it preserved its original Perfective functions: as negative Perfective (after the particle lam) in Arabic, in constructions with waw consecutioum in Hebrew, in archaic poetic texts in Ugaritic and Hebrew, after new suffixed Perfective in certain homogeneous constructions in Arabic (see more details and a complete presentation of this model of reconstruction in Porkhomovsky 2008). Further development of the basic binary opposition "Perfective vs. Imperfective" is well attested in modern Arabic dialects and in Tigrinya (Ethiopian Semitic). The same typological evolution is repeated in these languages for the second time. In Tigrinya the new strong suffix-conjugated Perfective became a weak unmarked member of the opposition, and this led to the formation of a new marked suffix-conjugated Perfective on the basis of the historical Gerund (nominal form).

It could be surmised that within the framework of the Semitic opposition 'Perfective vs. Imperfective' the perfective form is always weak (unmarked). However, evolution of the Arabic verbal system does not allow for this interpretation. As in all Semitic languages at the first stage of morphological evolution, Perfective in Arabic became weak, and a new suffixconjugated Perfective emerged. But in modern Cairene Arabic the Imperfective member of the basic opposition "Perfective vs. Imperfective", i.e. the prefix-conjugated form with reduced vocalism, became weak, and a new marked Imperfective emerged, formed by the prefix $b$-, added to the existing prefix-conjugated form with reduced vocalism. Since the form of Imperfective in classical Arabic is a reflex of the old weak Perfective, this evolution indicates that it is not the aspect semantics that determines which form becomes unmarked in the basic aspect opposition, but the decisive role is actually played by a formal criterion: the prefix-conjugated verbal form with reduced vocalism is the primary finite verbal form in Semitic, and all the other forms are derived from it. Thus, this form is a weak (unmarked) one par excellence.

In Tigrinya (as in all Modern South Arabian and Ethiopian Semitic languages) this form was pushed out of the aspect opposition and has retained only modal functions. In other words, the derived prefix-conjugated Imperfective form with full vocalism remained marked in Tigrinya, whereas the more simple suffix-conjugated Perfective form became weak. It may 
be added that the process of formation of new finite verbal forms within the Imperfective semantic field on the basis of participles, as attested in modern Arabic dialects (i.e. in Tunisian and Egyptian), belongs to the same diachronic typological trend.

3. The Neogrammarian paradigm (in the sense of [Kuhn 1962]) is valid only for the phonetic level, i.e. the establishment of regular sound correspondences. The format of the present paper does not allow for a detailed discussion of Kuhn's model of scientific evolution. Applied to linguistics, Kuhn's model means that comparative historical studies which do not tally with Neogrammarian principles are not compatible with standard (paradigmatic) comparative linguistics (cf. more on this in [Porkhomovsky 2013]). The standard approach is based on two axioms:

1) arbitrariness of the linguistic sign (with the exception of onomatopoeic words and Lallwörter);

2) uniqueness and continuity of the diachronic transmission of languages to new generations of speakers. This principle presumes the possibility of reconstructing only one proto-language for genetically related (parent) languages. The existence of mixed languages is not allowed for by this axiom. (The situation with pidgins and creoles deserves special discussion in this respect, but it lies outside the scope of the present paper.)

As to the higher (viz. morphological, syntactic and semantic) language levels, comparative historical studies at these levels cannot be considered paradigmatic in Kuhn's sense, since their linguistic data generally allow for multiple interpretations. The same applies to the problem of genealogical classifications: absolute classifications, which determine the very fact of genetic relationship, belong to the paradigmatic sphere of comparative linguistics, since absolute genetic status is determined on the basis of regular sound correspondences. On the contrary, the internal classification of parent languages into branches, groups and subgroups according to the genealogical tree model does not belong to the paradigmatic sphere of comparative linguistics because it depends on the interpretation of established isoglosses. The main problem here is to differentiate between genetically-based isoglosses and areal ones within the groups of related languages.

It is obvious that after the formation of the Neogrammarian comparative paradigm it became possible and necessary to distinguish between paradigmatic and non-paradigmatic approaches to historical linguistics, since they are not compatible and the same terms may reflect different notions. The non-paradigmatic approaches do not conform either to one of the axioms of the Neogrammarian paradigm mentioned above, or to both of them.

These non-paradigmatic models are quite numerous and widespread in historical linguistics. The reason for this obviously lies in the fact that comparative studies on levels higher than phonetic are not paradigmatic, so they allow for alternative approaches to genetic relationship. One of the earliest and the most influential is the conception of mixed languages, usually associated with the name of Hugo Schuchardt. Various linguistic schools and numerous authors belong to this trend in historical linguistics, e.g. the Italian neolinguistic school; one of the latest examples of this approach is R. Dixon's theory of punctuated equilibrium (Dixon 1997). These non-paradigmatic trends in diachronic language studies are usually based on typological and areal arguments.

Another theoretical approach to linguistic reconstruction, based on the epistemology of positivism, consists in the interpretation of the results of comparative studies only as sets of correspondences between languages. Forms not attested in real languages, extinct or living, are not taken into consideration, hence reconstructions of proto-languages are excluded from scientific analysis. In principle, this approach does not contradict the Neogrammarian para- 
digm. Incidentally, Antoine Meillet, a prominent figure in Indo-European comparative studies, was a proponent of positivism.

All these non-paradigmatic theories and hypotheses are often applied to linguistics as a whole, irrespective of what particular language families are involved. However, they are much more widespread in the comparative studies of language groups without long written traditions that were only recently included into professional linguistic analysis. This approach is less popular in relation to language families with long and rich written traditions that present abundant material for reconstruction of language archetypes.

Semitic languages make an obvious exception to this case. The idea to reconstruct ProtoSemitic archetypes was quite often met with reserve or even objected to throughout the history of Semitic comparative studies by numerous scholars, beginning with Carl Brockelmann and his predecessors and ending with contemporary authors. Apart from issues mentioned above and valid for comparative linguistics as a whole, there are special reasons for such an approach, specific for the Semitic area. One group of these reasons lies outside linguistics as such and is highly hypothetical. The Semitic language family includes languages of world religions and great ancient human civilizations - languages that preserve their special sociolinguistic status in modern times, irrespective of individual attitudes of particular researchers. This fact can create a certain psychological context, open or hidden (latent), which is not too favorable for the idea of reconstructing archetypes that underlie and antecede attested linguistic phenomena in these particular languages.

A more obvious and powerful reason pertains to the first Neogrammarian axiom mentioned above, i.e. arbitrariness of the linguistic sign. The phenomenon of stable correlations between phonetic forms and their semantic or pragmatic characteristics outside the group of evident onomatopoeic words and Lallwörter is attested in practically all languages of the world. In some languages this phenomenon is more widespread than in others, cf. the socalled "ideophones" in different African languages. The history of linguistics knows many attempts to use phonetic symbolism in particular languages and language families for glottogonic theories; however, it must be emphasized that Semitic languages as a whole, and the Arabic language first and foremost, have a certain privileged status in this linguistic trend.

A good example of it is A. Gazov-Ginzberg's work "Is language imitative by origin? (Evidence from common Semitic stock of roots)" (Gazov-Ginzberg 1965, in Russian with a brief English summary). The author claims to identify the following four groups of onomatopoeic lexemes on the basis of his typological analysis of imitative lexicon in many Semitic and nonSemitic languages with a special focus on Arabic and Hebrew (Gazov-Ginsberg 1965: 171-172):

A. "Internal imitation": 1. blowing, whiff, puff; 2. snuffing, breath; 3. sniffing (pshawing); 4. imbibing, sipping, sucking; 5. smacking (one's lips), champing; 6. licking, lapping, etc; 7. snapping (biting), chattering one's teeth; 8. spitting, sprinkling; 9. labial vibrant pshawing; 10. snoring, hoarseness; 11. choking; 12. laughter; 13. sighing, moaning; 14. crying, roaring; 15. whistle, hissing; 16. whispering, babbling, murmuring, etc; 17. keeping mum, hushing; 18. hopping; 19. trembling; 20. expiration for warming (one's hands, etc).

B. "External imitation": 1. animal voices (different animals and birds); 2. tramping, stamping, stepping; 3. grasping, grabbing, gripping; 4. slapping, clapping (one's hands); 5. knocking, tapping; 6. rumble (of thunder), rattle; 7. breaking, crack, crash, etc; 8. creak, scrunch, chirr, etc; 9. rustle, rash; 10. slipping, sliding, gliding; 11. slitting; 12. bursting; 13. bubbling; 14. splash (of water); 15. dripping; 16. fluttering (of a bird), hum, buzz (of an insect); 17. tinkling, ringing. 
C. Gestures of oral organs: 1. opening one's mouth; 2. shutting one's mouth; 3. pouting (one's lips); 4. stretching (sinking) one's cheeks; 5. imitation of full mouth; 6 . lolling out (one's tongue); 7. squeezing, clenching (one's teeth); 8. total constriction; 9. imitation of urination; 10. names of vocal (oral) organs.

D. Babbling (nursery) words.

It is evident that the author's answer to the question that constitutes the title of his book is positive, hence, not compatible with Neogrammarian paradigm. He claims that Semitic languages have preserved the most archaic state in the process of the formation of the human language. The special status of Semitic languages and the exclusive status of Arabic, sometimes together with Hebrew, is accounted for by the specific structure of the Semitic consonant root. The triconsonantal structure of the Semitic root, where one of the consonants is prone to various alternations, is a very convenient object for different glottogonic theories, since it presents various possibilities to correlate the phonetic value of these alternating consonants with semantic shifts in the respective consonantal root. Different theoretical models to analyze consonantal root alternations in Semitic languages were put forward in the works of certain Russian Semitologists of the first half of the $20^{\text {th }}$ century. Thus, in order to explain these consonantal variations, N. Yushmanov postulated the existence in Proto-Semitic of "diffuse" phonemes (or "archiphonemes"). According to him, each of these diffuse phonemes may be a source of several phonemes in particular Semitic languages (Yushmanov 1998: 126-191). S. Mayzel' presented a detailed analysis of consonantal variants in Semitic triconsonantal roots and a semantic typology of these variations (Maisel' 1983; see more on this in Porkhomovsky 2007). G. Bohas proposed a different approach to these consonantal variations within the framework of his model "matrices et étymons" (Bohas 1997, 2000).

Alternations of root consonants are characteristic of Semitic languages in general, but Arabic is especially rich in this respect (with the second place obviously belonging to Hebrew). There is no doubt that data, collected by the authors of the above-mentioned works, and their typological analysis make an important contribution to Semitic linguistics. At the same time these alternations often violate regular sound correspondences; for this reason, it is difficult to make a choice between alternating consonants and to decide what particular variant should be considered a reflex of the prototype. For this reason the task of reconstructing Proto-Semitic archetypes is often viewed with reserve or is even considered utterly impossible. In my opinion, this is the main obstacle on the way towards the creation of a comprehensive Semitic etymological dictionary with reconstructions of common roots, cf. the following comment by I. Diakonoff:

It is necessary to point out a very interesting phenomenon which is rather widely spread in Semitic languages (especially in Arabic) but not unknown in other language families. This phenomenon consists of semantic connection between phonetically (acoustically or articulatorily) close roots, which are not regular reflexes. Thus, cf. the following root series in Arabic: ksr, ksf, qsm..., qt?', qțt, qtl < ${ }^{*} \mathrm{qṭl}$... All these roots have the meaning 'to cut off', 'to tear', 'to break off' etc. ... Probably this is a case of onomatopoeia, not only direct (imitation of natural sounds) but also secondary (imitation of already existing roots)... It is also quite evident that phonic incompatibilities valid for one dialect, but not for another, also played their part, as well as interdialectal loans... Be it as it may, the phenomenon in question is yet one more means of word-formation, not studied before, and which is probably diachronically rather late. (Diakonoff 1988: 55-56, note 13)

Thus, the problem of root consonant alternations in Semitic may be summarized as follows. The analysis of this phenomenon is an important part of Semitic linguistics, but attempts to consider it as an argument for glottogonic hypotheses cannot be accepted, since it is not 
possible to consider Arabic or even Proto-Semitic as direct reflexes of the original human language. Most likely, these late alternations result from the powerful mechanism of development by analogy, which was best pronounced or best preserved in Arabic. But at the same time these evident facts of Semitic languages and, above all, of Arabic language structures served as additional reasons for the negative attitude towards the reconstruction of ProtoSemitic archetypes in comparative Semitic studies.

Conclusion. The main goal of the present paper was to focus on certain aspects which make Semitic languages a special case within the framework of comparative linguistics. The particular choice of Arabic for most of the illustrations was natural, since it presents the archetypal, most evident case of these specific features, falling into three different groups, viz. (1) correlation between classical languages of great civilizations of the Ancient Near East and world religions and modern unwritten languages in the context of comparative studies and reconstructions, (2) a most unusual situation in the Semitic tense-aspect-mood verbal system that made straightforward reconstruction of the Proto-Semitic verbal system and its further evolution practically impossible, (3) consonantal alternations and variants within triconsonantal Semitic roots that became a serious obstacle to the reconstruction of Proto-Semitic lexicon.

At first glance, these three aspects have nothing in common, but one should take into account their combined cumulative effect on the formation and development of Semitic comparative studies. This resulted in the paradoxical state of the art that is characterized by a very high level of comparative studies, viz. establishing correspondences on all language levels, combined with an obvious reluctance towards proto-language reconstructions.

Concerning the first aspect, the most evident result is that only during the last decades non-written languages of Southern Arabia and Ethiopia were included into comparative studies on par with classical languages. This almost immediately brought about a real scientific revolution (in Kuhn's terminology) in comparative phonetics, morphology and internal classification of Semitic languages. The second aspect, viz. the Semitic verbal system in comparative context, may well provoke a teleological approach, since it makes another serious obstacle to the reconstructions of Proto-Semitic. The note by A. Meillet, cited above, emphasizes this very strange situation. The system of three verbal aspects is attested in Semitic languages and its semantic cells are filled with three morphological units which are obviously identical in their structures; hence, they must be derived from the same proto-forms. At the same time the correlations between semantic and formal sides of these categories are opposite in different Semitic language groups as far as the main binary aspect system perfective vs. imperfective is concerned, and this does not allow to arrive at a sound proto-level reconstruction. The solution of this problem, proposed by the present author, allows to overcome this obstacle and, as a result, to propose a consequent internal genealogical classification of Semitic. However, it should be noted that this reconstruction is based not on the Neogrammarian principle of the comparison of forms with the focus on phonetic and morphonological criteria, but on reconstructions within the framework of diachronic typology. This approach seems justified, since morphology is systematic and the evolution of the system may well be a more powerful factor than the phonetic evolution of forms. Arabic language presents the most straightforward case of a verbal system evolution from the postulated proto-Semitic stage towards classical Arabic and further on to modern spoken dialects.

The shift of consonants in the Semitic root, discussed in the last part of this article, presents a serious methodological problem, since it allows to challenge the principle of arbitrariness of the language sign, which is a basic axiom of the comparative paradigm. Again, it is in Arabic that we find the most abundant data in favor of such an approach. In any case, the exis- 
tence of this phenomenon is not a hindrance towards establishing regular sound correspondences and reconstructing the phonological system of Proto-Semitic. The problem is in reconstructing particular proto-language consonantal roots, since one must either postulate a large amount of quasi-synonyms with minimal phonetic differences or to select one root in a particular semantic and phonetic lexical group as a prototypical one and to explain away other roots as consonantal variants. As a result, even though the overall level of Semitic lexicography is very high and the fundamental dictionaries of classical languages comprise abundant lexical cognates from other Semitic languages, the task of compiling a comprehensive Semitic etymological dictionary is far from actual realization.

In conclusion, it is possible to assert that Semitic historical linguistics is characterized by a very high level of comparative studies as such, yet the same cannot be said about protolanguage reconstructions of grammar and vocabulary which should normally be an integral part of any comparative studies.

\section{References}

Bohas, Georges. 1997. Matrices, étymons, racines. Éléments d’une théorie lexicologique du vocabulaire arabe. Louvain: Peeters.

Bohas, Georges. 2000. Matrices et étymons. Développement de la théorie. Lausanne: Éditions du Zèbre.

Cassuto, Philippe. 2007. Base, roi et serviteur. In: Philippe Cassuto and Pierre Larcher (eds.). La formation des mots dans les langues sémitiques. Aix-en-Provence: Publications de l'Université de Provence, pp. 15-43.

Dhorme, Édouard. 1956. Introduction. In: La Bible. Ancien Testament. Bibliothèque de la Pléiade. Éditions Gallimard. Vol. 1, pp. XI-CXIX.

Dhorme, Édouard. 1956. Les Juges. / Notes. In: La Bible. Ancien Testament. Bibliothèque de la Pléiade. Éditions Gallimard. Vol. 1, pp. 715-809.

Diakonoff, Igor M. 1988. Afrasian languages. Moscow: Nauka.

Dixon, Robert M. W. 1997. The rise and fall of languages. Cambridge: University Press.

Kuhn, Thomas Samuel. 1962. The Structure of Scientific Revolutions. Chicago: University of Chicago Press; 2nd edition, enlarged, 1970.

Meillet, Antoine. 1927. Sur le degré de précision qu'admet la définition de la parenté linguistique. In: F. Boas et al. (eds.). Festschrift Meinhof. Glückstadt-Hamburg: Kommissions Verlag von L. Friederichsen., gedruckt bei J.J. Augustin, pp. 444-448.

Porkhomovsky, Victor. 1997. Modern South Arabian languages from a Semitic and Hamito-Semitic persperctive. Proceedings of the Seminar for Arabian studies 27, pp. 219-223.

Porkhomovsky, Victor. 2001/2002. Le subjonctif en socotri et les problèmes de reconstruction du système verbal en sémitique. Linguistique arabe et sémitique, tome II, pp. 183-195.

Porkhomovsky, Victor. 2007. La structure de la racine et la formation des mots dans la tradition sémitologique russe. In: Philippe Cassuto and Pierre Larcher (eds.). La formation des mots dans les langues sémitiques. Aix-enProvence: Publications de l'Université de Provence, pp. 45-52.

Porkhomovsky, Victor. 2008. Hamito-Semitic aspect system: the case of Semitic and Berber. Sprache und Geschichte in Afrika, Band 19, Köln: Rüdiger Köppe Verlag, pp. 155-173.

Газов-Гинзберг, А.М. 1965. Был ли язык изобразителен в своих истоках? Свидетельство прасемитского запаса корней. М.: Наука. [Gazov-Ginzberg, Anatoliř. 1965. Byl li yazyk izobrazitelen v svoikh istokakh? Svidetel'stvo prasemitskogo zapasa korney. Moskva: Nauka.]

Майзель, С.С. 1983. Пути развития корневого фонда семитских языков. М.: Наука. [Mayzel', Solomon. 1983. Puti razvitiya kornevogo fonda semitskikh yazykov. Moskva : Nauka]

Наумкин В.В., Порхомовский В.Я. 1981. Очерки по этнолингвистике Сокотры. М.: Наука. [Naumkin, Vitaly; Porkhomovsky, Victor. 1981. Ocherki po etnolingvistike Sokotry. Moskva: Nauka] 
Порхомовский В.Я. 2013. Сравнительно-историческое языкознание как парадигматическая наука. В: Языковые параметры современной цзиилизац̧ии. М.: Институт языкознания РАН. Стр. 127-136. [Porkhomovsky, Victor. 2013. Sravnitel'no-istoricheskoye yazykoznaniye kak paradigmaticheskaya nauka. Yazykoviye parametry sovremennoy tsivilizatsii. M., Nauka. Pp. 127-136]

Юшманов Н.В. 1998. Структура семитского корня. В: Юшманов Н.В. Избранные труды. М.: Восточная литература. Стр. 126-199. [Yushmanov, Nikolay. 1998. Struktura semitskogo kornya. In: Yushmanov, Nikolay. Izbranniye trudy. Moskva: Vostochnaya literatura, pp. 126-199].

\section{В. Я. Порхомовский. Арабский язык в контексте сравнительных исследований.}

В статье обсуждаются некоторые характерные особенности арабского языка, определившие его место в семитских сравнительных исследованиях. В основе этих особенностей лежат не только структуры арабского языка разных уровней, но и экстралингвистические факторы, прежде всего социокультурные и психологические. Подобное сочетание лингвистических и экстралингвистических факторов делают арабский язык уникальным феноменом среди языков мира. Прежде чем рассматривать место арабского языка в семитологии дается краткий обзор истории внутрисемитских сравнений до возникновения современного сравнительного языкознания и роли в этом плане средневековой арабской грамматической традиции. В фокусе следующего раздела статьи находится роль арабского языка как эталона для протосемитских реконструкций, а также обсуждаются коренные изменения, которые претерпела эта роль в истории сравнительных семитских исследований. В заключительном разделе рассматриваются некоторые характерные черты арабской и семитской фонетики и лексики и их соотношение со стандартной младограмматической парадигмой сравнительного языкознания. Эта проблематика заслуживает специального внимания, поскольку теории, опирающиеся на эти феномены, выходят за рамки стандартной парадигмы сравнительной лингвистики, а арабский язык может рассматриваться как архетипический пример подобных феноменов.

Ключевые слова: сравнительное языкознание, семитские языки, арабский язык, младограмматическая парадигма, регулярные соответствия, реконструкция, бинарная оппозиция, перфектив, имперфектив, историческая типология. 
